\title{
Pax-8 protein levels regulate thyroglobulin gene expression
}

\section{Fabbro, L Pellizzari, F Mercuri, G Tell and G Damante}

Dipartimento di Scienze e Tecnologie Biomediche, Università di Udine, Piazzale Kolbe 1, 33100 Udine, Italy

(Requests for offprints should be addressed to G Damante)

\begin{abstract}
Pax proteins are transcription factors that control differentiation of several cell types. In adult organisms Pax-8 is expressed in the follicular thyroid cell where it interacts with sequences of thyroglobulin and thyroperoxidase promoters. In this study, we provide evidence indicating that Pax-8 protein levels regulate thyroglobulin gene transcription. The most critical approach consisted in increasing Pax-8 protein levels by transfecting thyroid cells with a Pax-8 expression vector. In this situation the thyroglobulin promoter transcriptional activity was significantly increased with respect to untransfected cells. In contrast, the transfection of thyroid transcription factor-1 (TTF-1) expression
\end{abstract}

vector causes a modest decrease of thyroglobulin promoter activity, rather than an increase. Northern blots of human papillary cancers reveal a significant correlation between Pax-8 and thyroglobulin mRNAs. Gel-retardation assays suggest that the mechanism by which the Pax-8 protein levels modulate thyroglobulin promoter activity may occur through competition with TTF-1 for a common binding site. Since we also demonstrate that Pax-8 expression is subjected to TSH control, our data strongly suggest that $\mathrm{Pax}-8$ protein levels could represent an important determinant for the regulation of thyroid cells.

Fournal of Molecular Endocrinology (1998) 21, 347-354

\section{INTRODUCTION}

Pax proteins control several developmental decisions in a wide spectrum of organisms ranging from nematodes to vertebrates (Stuart et al. 1993, Chamberlin et al. 1997). These proteins act as transcription factors and recognize specific DNA sequences through an evolutionarily conserved structure, the paired domain (Strachan \& Read 1994, Xu et al. 1995). Pax genes mutations give rise to several abnormal phenotypes in mice and genetic diseases in humans (Mansouri et al. 1996). Moreover, misexpression or structural abnormalities of Pax proteins contribute to the generation/ progression of several human tumours (Stuart \& Gruss 1995, Tell et al. 1997). The function of Pax genes appears to be very sensitive to the amount of functional protein product. In fact, haploinsufficiency is a characteristic of the abnormal phenotypes due to Pax genes mutations: although the effect of mutations is more pronounced in homozygous subjects, abnormal phenotypes are also usually observed in heterozygous subjects (Read 1995). Moreover, for Pax-6 it has also been demonstrated that an increase in gene dosage may give rise to abnormal phenotypes (Schedl et al.
1996). Thus, the amount of Pax protein appears to be so strictly poised that even subtle changes might severely perturb cell functions. Such a picture may suggest that modulation of the amount of Pax proteins could be used as a sensitive switch to regulate cell function.

Pax-8 is expressed in follicular thyroid cells of adult organisms where it activates transcription of thyroglobulin ( $\mathrm{Tg}$ ) and thyroperoxidase (TPO) genes (Zannini et al. 1992, van der Kallen et al. 1996). Recent studies on human congenital hypothyroidism demonstrate that $\mathrm{Pax}-8$ plays an important role in thyroid development (Macchia et al. 1998). The thyroid follicular cell is subjected to a feedback regulation by thyrotrophin (TSH), through cAMP-dependent mechanisms. Recently, it has been demonstrated that Pax-8 expression in primary dog thyrocytes is increased by the adenylate cyclase activator, forskolin (Van Renterghem et al. 1996). Moreover, Pax-8 mRNA was increased in Graves' thyroids with respect to normal tissue (Schuppert et al. 1996). Pax-8 mRNA levels may correlate with Tg, TPO, and thyrotrophin receptor transcript levels (Fabbro et al. 1994, Schuppert et al. 1996). Altogether, these findings may suggest that Pax-8 protein levels play a 
(a)

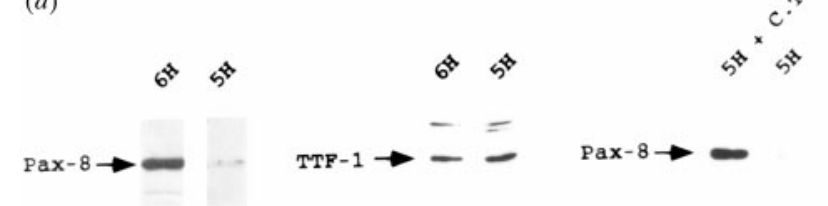

(b)

Time after TSH addition (days)

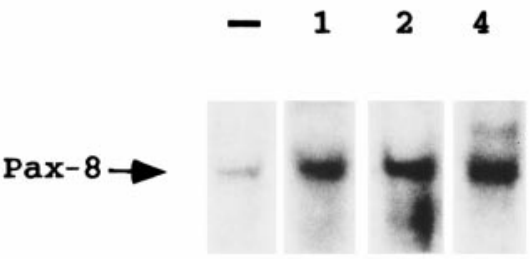

FIGURE 1. TSH and cholera toxin increases Pax-8 protein levels. (a) FRTL-5 cells were treated with TSH $(1 \mathrm{mU} / \mathrm{ml})(6 \mathrm{H})$, without TSH $(5 \mathrm{H})$ or with cholera toxin $(1 \mu \mathrm{g} / \mathrm{ml})(5 \mathrm{H}+\mathrm{C} . \mathrm{T}$.) for 4 days. (b) FRTL-5 cells were kept for 6 days in the absence of TSH, then the hormone was added at a final concentration of $1 \mathrm{mU} / \mathrm{ml}$. At the indicated times the incubation was stopped and nuclear extracts prepared. Equal amounts of total proteins of nuclear extract $(12 \mu \mathrm{g})$ were resolved by SDS-PAGE. Pax-8 and TTF-1 protein levels were detected by Western blot using an ECL kit provided by Amersham.

role in the regulation of differentiated function of thyroid cells. In this study evidence corroborating this hypothesis is provided. We demonstrate that $\mathrm{Tg}$ gene promoter is regulated by $\mathrm{Pax}-8$ protein levels. Moreover, a significant correlation of Pax-8 and $\mathrm{Tg}$ mRNAs is found in human papillary carcinomas. Since we also demonstrate that $\mathrm{Pax}-8$ expression is subjected to TSH control, our data strongly suggest that Pax- 8 protein levels could represent an important determinant for the regulation of thyroid cells.

\section{MATERIALS AND METHODS}

\section{Tissue collection and Northern blots}

Tissues from papillary tumours were obtained from patients undergoing surgery. Tumour fragments of about $0.5 \mathrm{~cm}^{3}$ were quickly frozen. The absence of contaminating normal tissue was confirmed by histological analysis. Total RNA from frozen tissues was prepared by the guanidinium-thiocyanate acid-phenol procedure (Chomczynski \& Sacchi 1987). Northern blot was performed using standard procedures, formaldehyde/agarose gel and filter hybridization using the protocol described (Church $\&$ Gilbert 1984) and, at the end, the filter was exposed at $-80{ }^{\circ} \mathrm{C}$ for autoradiography. The intensity of the signals was quantitated by scanning densitometry of the autoradiograms. The DNA fragments used as probes in Northern analysis were: for Pax-8, a HindIII/EcoRI fragment of human Pax-8 cDNA contained in plasmid H26P/ $\mathrm{S} 3$; for thyroid transcription factor-1 (TTF-1), the $0.7 \mathrm{~Kb}$ SacI fragment of plasmid prTTF1/4; for glyceraldeyde-3-phosphate dehydrogenase (GAPDH), a $1.3 \mathrm{~kb}$ PstI fragment of plasmid pGAPDH1 containing the coding region of GAPDH.

\section{Protein expression and gel-retardation assay}

The DNA-binding domain of TTF-1 (TTF-1HD) was prepared as described (Damante et al. 1996). The Pax-8 DNA-binding domain (Pax-8Prd) was prepared as follows. The DNA fragment encoding for the Pax-8Prd was amplified by PCR using the oligonucleotides $\mathrm{Pb} 1$ : 5'-GGCGCGGATCCATC

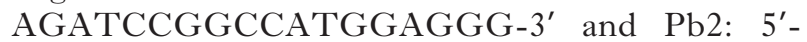
CCGCGGGATCCGGGGAGGTTGAATGGCT GCTG-3'. The PCR reaction was performed by using the plasmid CMV-Pax-8 kindly provided by $\mathrm{P}$ Gruss as a template. PCR products were BamHI digested and cloned in the BamHI site of p T7.7 polylinker. The obtained plasmid was used to transform BL21 bacterial strain (Studier \& Moffat 1986). Transformed cells were grown at $37^{\circ} \mathrm{C}$ to $\mathrm{OD}_{600} 0 \cdot 6-0 \cdot 7$ and then induced by $1 \mathrm{mM}$ isopropyl $\beta$-D-thiogalactopyramoside for $3 \mathrm{~h}$. Cells were harvested by centrifugation and resuspended in lysis buffer $(50 \mathrm{mM}$ sodium phosphate buffer $\mathrm{pH}$ $7 \cdot 0,0 \cdot 25 \mathrm{M} \mathrm{NaCl}, 1 \mathrm{mM}$ EDTA, $1 \mathrm{mM}$ EGTA, $1 \mathrm{mM}$ dithiothreitol (DTT), $2 \mu \mathrm{g} / \mathrm{ml}$ leupeptin, $2 \mu \mathrm{g} / \mathrm{ml}$ pepstatin, $1 \mathrm{mM}$ phenylmethylsulphonyl fluoride (PMSF)) in a volume of $10 \mathrm{ml} / \mathrm{g}$ bacterial pellet. After cell lysis by sonication, the bacterial debris was removed by centrifugation. DNA was removed by addition of protamine sulphate to the supernatant to $0.3 \mathrm{mg} / \mathrm{ml}$ and the precipitate removed by centrifugation. The supernatant was then loaded onto a Mono-S column (Pharmacia, Uppsala, Sweden) pre-equilibrated with lysis buffer. The Pax- 8 paired domain was purified using a linear gradient of $0.25-0.7 \mathrm{M} \mathrm{NaCl}$ in $50 \mathrm{mM}$ phosphate buffer $\mathrm{pH} 7 \cdot 0$ that contained $1 \mathrm{mM}$ DTT. The purified protein gave a single band on an overloaded SDS-PAGE.

Gel-retardation assays were performed by the incubation of purified proteins or nuclear extracts and DNA in a buffer containing $20 \mathrm{mM}$ Tris- $\mathrm{HCl}$ 
(a)

Tg promoter

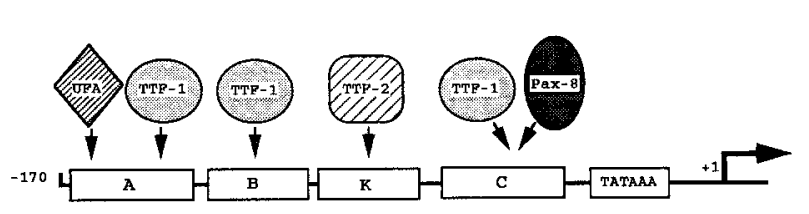

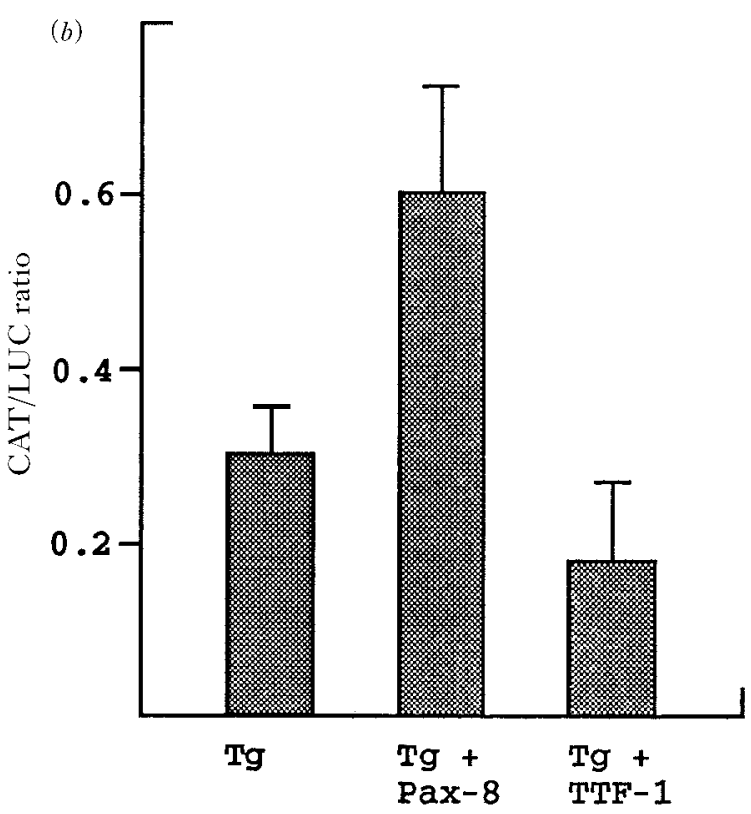

FIGURE 2. Pax-8 overexpression in FRTL-5 cells increases Tg promoter activity. (a) Schematic structure of the Tg promoter. Open boxes indicate the sites bound by the transcription factors indicated above. Note that the binding of TTF-1 or Pax-8 to the C site is mutually exclusive. (b) FRTL-5 cells were transfected with Tg promoter ( $3 \mu \mathrm{g}$ ) (Tg), Tg promoter $(3 \mu \mathrm{g})+\mathrm{Pax}-8$ expression vector $(5 \mu \mathrm{g})(\mathrm{Tg}+\mathrm{Pax}-8)$, or Tg promoter $(3 \mu \mathrm{g})+\mathrm{TTF}-1$ expression vector $(5 \mu \mathrm{g})(\mathrm{Tg}+\mathrm{TTF}-1)$. In both TTF-1 and Pax-8 expression vectors, the protein expression is driven by the CMV promoter. In all conditions a plasmid expressing the LUC gene was cotransfected $(1 \mu \mathrm{g})$ to normalize the CAT activity for the efficiency of transfections. Therefore, results are expressed as the CAT/LUC ratio. Each bar represents the mean value \pm S.D. of four independent experiments.

$\mathrm{pH} 7 \cdot 6,75 \mathrm{mM} \mathrm{KCl}, 0 \cdot 25 \mathrm{mg} / \mathrm{ml}$ bovine serum albumin (BSA), $5 \mathrm{mM}$ DTT, $10 \mu \mathrm{g} / \mathrm{ml}$ calf thymus DNA, and $10 \%$ glycerolfor $30 \mathrm{~min}$ at room temperature. Oligonucleotides $\mathrm{C}, \mathrm{C} \pi$ and $\mathrm{D} 1$ were used as probes. The sense strands of these oligonucleotides are:

\section{C: 5'-CACTGCCCAGTCAAGTGTTCT \\ C $\pi$ : 5'-TCAGTCACGCGTGACTGGGCA TGA-3'; \\ D1: 5'-ACGATGAGTGGCTCATAAAT GTG-3'; CG-3'.}

Oligonucleotides were labelled at the $5^{\prime}$ end using polynucleotide kinase and $\left[{ }^{32} \mathrm{P}-\gamma\right] \mathrm{ATP}$ and annealed with respective complementary strand. At the end of the binding reaction, samples were loaded on a $7 \cdot 5 \%$ native polyacrylamide gel and run at $8{ }^{\circ} \mathrm{C}$ in $0.5 \times$ Tris-borate-EDTA.

\section{Cell culture and transfection}

FRTL-5 cells were grown as previously described (Ambesi-Impiombato \& Coon 1979). For the transient transfection assay, cells were plated at $1.5 \times 10^{6}$ cells $/ 100-\mathrm{mm}$ tissue culture dish $48 \mathrm{~h}$ prior to transfection. Three hours prior to transfection, the medium was changed to Dulbecco's modified Eagle's medium containing 5\% calf serum and growth factors. Transfection was carried out by calcium phosphate co-precipitation as described before (Francis-Lang et al. 1992). The plasmid containing $\mathrm{Tg}$ promoter linked to the CAT gene is described in Musti et al. (1987). In both TTF-1 and Pax-8 expression vectors, the protein expression is driven by the cytomegalovirus promoter (CMV) (Zannini et al. 1992). To monitor the transfection efficiency, a plasmid containing the luciferase gene (LUC) under the control of the CMV promoter (CMV-LUC) was used.

\section{Nuclear extracts and Western blot}

Nuclear extracts of FRTL-5 and NIH 3T3 cells were prepared as follows. Cell pellets were resuspended in a solution containing $10 \mathrm{mM}$ Hepes pH 7.9, $10 \mathrm{mM} \mathrm{KCl}, 1.5 \mathrm{mM} \mathrm{MgCl}_{2}, 0.1 \mathrm{mM}$ EGTA, $2 \mathrm{mM}$ DTT, and $0.5 \mathrm{mM}$ PMSF. Cells were then broken-up by passing through a 25 -gauge needle; nuclei were pelleted, washed with the same buffer and resuspended in a solution containing 


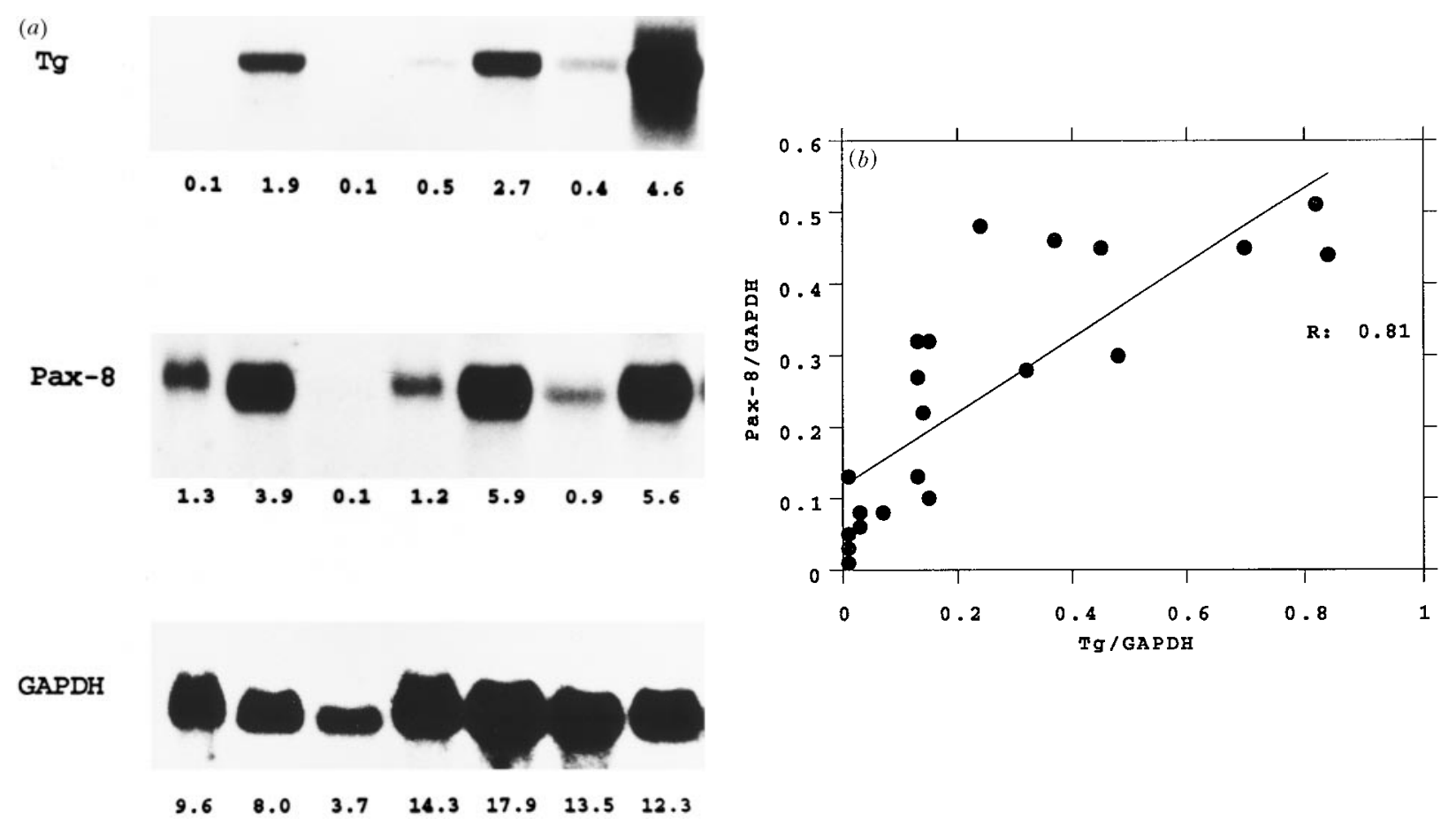

FIgure 3. Correlation between Pax-8 and Tg mRNA levels in human papillary tumours. Northern blot analysis was performed as described in Materials and Methods. (a) Representative autoradiographic signals for Tg, Pax-8 and GAPDH mRNA; the value below each autoradiogram indicates the quantitation of the signal performed by densitometric scanning. (b) Plot of the Tg/GAPDH ratio versus Pax-8/GAPDH ratio of 21 papillary cancers.

$10 \mathrm{mM}$ Hepes pH 7.9, $400 \mathrm{mM} \mathrm{NaCl}, 1 \cdot 5 \mathrm{mM}$ $\mathrm{MgCl}_{2}, \quad 0.1 \mathrm{mM}$ EGTA, $2 \mathrm{mM}$ DTT, $0.5 \mathrm{M}$ PMSF, and 5\% glycerol. After $30 \mathrm{~min}$ on ice, samples were spun and supernatant collected and stored at $-80^{\circ} \mathrm{C}$. Protein concentrations were determined colorimetrically as described previously (Bradford 1976). To perform Western blot analysis, nuclear extracts were boiled in Laemmli sample buffer and resolved by $12 \%$ SDS-polyacrylamide gel electrophoresis. After electroblotting onto a nitrocellulose membrane, Pax-8 and TTF-1 were localized by specific rabbit polyclonal antibodies (provided by R Di Lauro). The secondary antibody was horseradish peroxidase conjugated anti-rabbit immunoglobulin G (Sigma, St Louis, MO, USA). The membrane was developed with an Amersham ECL (enhanced chemioluminescence) detection kit (Amersham Life Science Ltd, Little Chalfont, Bucks, UK) and exposed to Kodak BioMax Light-1 films.

\section{RESULTS}

TSH is the main regulator of thyroid cell function. Therefore, if Pax -8 protein levels play an important role in the control of thyroid cell function they could be subjected to TSH regulation. This possibility was tested in the experiment shown in Fig. 1. FRTL-5 cells were incubated in the presence $(6 \mathrm{H})$ or absence $(5 \mathrm{H})$ of TSH $(1 \mathrm{mU} / \mathrm{ml})$ for 4 days (Fig. 1a). Equal amounts of total proteins present in nuclear extracts were run on SDS-PAGE and either Pax-8 or TTF-1 was detected by Western blot. The presence of TSH elicits a great increase in Pax-8, but not in TTF-1 protein levels. In order to test whether the TSH effect is mediated by cAMP-dependent mechanisms, FRTL-5 cells were kept for 4 days in the presence of cholera toxin $(1 \mu \mathrm{g} / \mathrm{ml})(5 \mathrm{H}+\mathrm{C} . \mathrm{T}$. $)$ in place of TSH. The large increase in Pax-8 in the presence of cholera toxin indicates that Pax- 8 protein levels are controlled by a cAMP-dependent mechanism. A time course of the TSH effect on Pax-8 protein levels was also performed. FRTL-5 cells were kept for 6 days in the absence of hormone and then subjected to TSH stimulation $(1 \mathrm{mU} / \mathrm{ml})$ for 1,2 and 4 days. Results are shown in Fig. $1 b$. After $24 \mathrm{~h}$ of TSH addition the increase in Pax-8 levels was nearly maximal. These results are similar to those obtained by Van Renterghem et al. (1996) using primary dog thyrocytes. Therefore, in different thyroid cell 
models TSH increases Pax-8 levels through cAMP-dependent mechanisms. It is noteworthy that previous studies have demonstrated that upon TSH addition TTF-1 protein levels are either down-regulated in FRTL-5 cells (Saito et al. 1997) or almost unchanged in primary dog thyrocytes (Kozmik et al. 1993). In our experimental conditions, TSH does not significantly modify TTF-1 protein levels.

A cell transfection approach was used to test whether Pax-8 protein levels regulate one of the differentiated functions of the thyroid cells, the transcriptional activity of Tg promoter (Fig. 2). The schematic structure of the $\mathrm{Tg}$ promoter, together with the transcription factors binding to it, is shown in Fig. 2a. FRTL-5 cells were transfected with $\mathrm{Tg}$ promoter linked to the CAT reporter gene in the absence or presence of plasmids expressing either Pax-8 or TTF-1. Results are shown in Fig. $2 b$. Tg promoter is active in FRTL-5 cells. However, the presence of Pax-8 expression vector significantly increases $\mathrm{Tg}$ promoter activity $(P<$ $0 \cdot 01)$. The effect appears to be specific since the cotransfection with the TTF-1 expression vector elicits a modest, but significant $(P<0 \cdot 05)$, reduction in the activity of this promoter, rather than an increase.

Pax-8 and Tg gene expression is very heterogeneous in human thyroid tumours (Fabbro et al. 1994). In order to test whether the findings obtained using FRTL-5 cells may have relevance in vivo, the correlation existing between Pax-8 and Tg mRNA levels in human papillary tumours was measured by Northern blot. Representative Northern blots are shown in Fig. $3 a$. After densitometric scanning of Tg and Pax- 8 mRNA signals, a significant correlation between Pax-8 and Tg mRNA levels was found (Fig. 3b). Such a correlation would suggest that the levels of Pax-8 may also control $\mathrm{Tg}$ gene expression in vivo.

Pax-8 and TTF-1 bind to overlapping sequences of the $\mathrm{C}$ site of the $\mathrm{Tg}$ promoter and in vitro studies revealed that a large excess of TTF-1 abolishes Pax-8 binding (Zannini et al. 1992). Since transfection of FRTL-5 cells with a TTF-1 expression vector elicits a subtle decrease in $\mathrm{Tg}$ promoter activity (Fig. 2), a dynamic equilibrium in the occupancy of the C site by TTF- 1 and Pax- 8 may be envisaged. Therefore, the molecular mechanism by which overexpression of $\mathrm{Pax}-8$ increases $\mathrm{Tg}$ promoter activity may occur through competition with TTF-1 for the common binding site. This hypothesis predicts that increasing amounts of Pax- 8 should displace TTF-1 from the C site of the $\mathrm{Tg}$ promoter. Such a possibility was tested by gel-retardation assay, using the purified DNA-

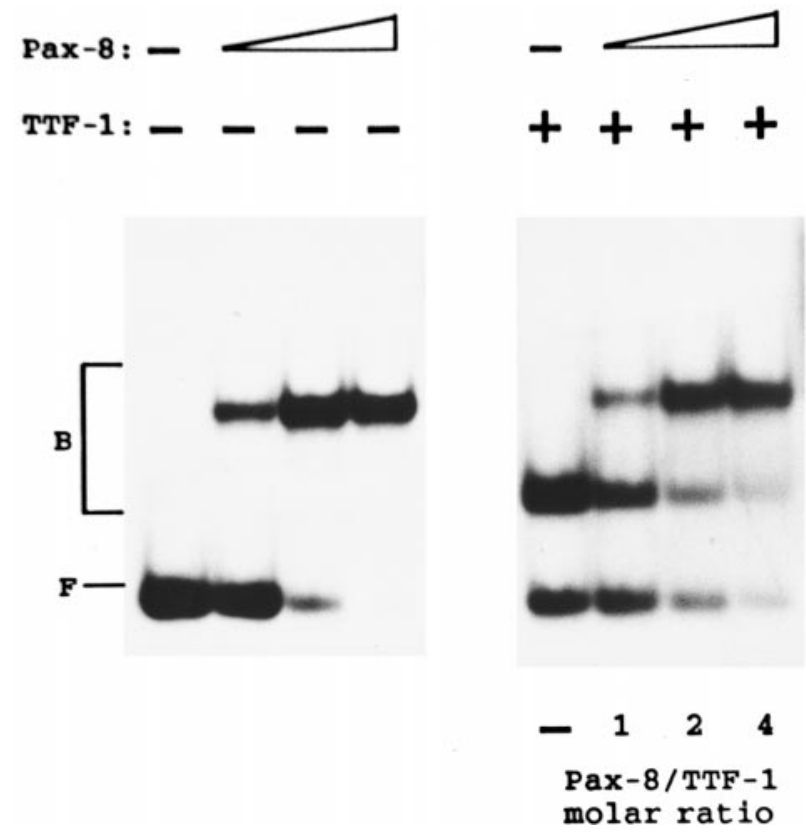

Figure 4. Pax-8 is able to displace TTF- 1 from the $\mathrm{C}$ site of the $\mathrm{Tg}$ promoter. The $\mathrm{C}$ site of the $\mathrm{Tg}$ promoter was incubated in the absence $(-)$ or presence $(+)$ of TTF-1 for $15 \mathrm{~min}$. Then, an increasing amount of Pax- 8 was added. Samples were incubated for an additional $20 \mathrm{~min}$ and then subjected to gel-retardation assay. F, free DNA; B, protein-bound DNA.

binding domains of Pax-8 and TTF-1 (Fig. 4). Increasing amounts of Pax- 8 were added to a preassembled TTF-1/C complex. At a Pax-8/TTF1 molar ratio of 2, TTF-1 binding was significantly reduced. Together with the data obtained using transfected cells (Fig. 2), this experiment suggests the existence of a dynamic equilibrium between Pax- 8 and TTF-1 for the occupancy of the C site of the $\mathrm{Tg}$ promoter.

To test whether the Pax-8/TTF-1 competition occurs in vivo it is necessary to evaluate the relative amount of Pax- 8 and TTF-1 in nuclear extracts of thyroid cells. We have recently identified oligonucleotides able to bind Pax- 8 but not TTF-1 and vice versa (Fabbro et al. 1996, L Pellizzari \& G Damante, unpublished data). As shown in Fig. $5 a$, oligonucleotide $\mathrm{C} \pi$ is specifically recognized by Pax- 8 but not by TTF-1; on the other hand, oligonucleotide D1 is recognized by TTF-1 but not by Pax-8. Both $\mathrm{C} \pi$ and D1 oligonucleotides are bound by FRTL-5 nuclear extracts but not by NIH 3T3 nuclear extracts, indicating that both are recognized only by thyroid-specific factors. By using the $\mathrm{C} \pi$ and $\mathrm{D} 1$ oligonucleotides as cold competitors of the $\mathrm{C}$ sequence, the first should 
(a)

Lases : $\begin{array}{lllllllllllllll}1 & 2 & 3 & 4 & 5 & 6 & 7 & 8 & 9 & 10 & 11 & 12 & 13 & 14 & 15\end{array}$

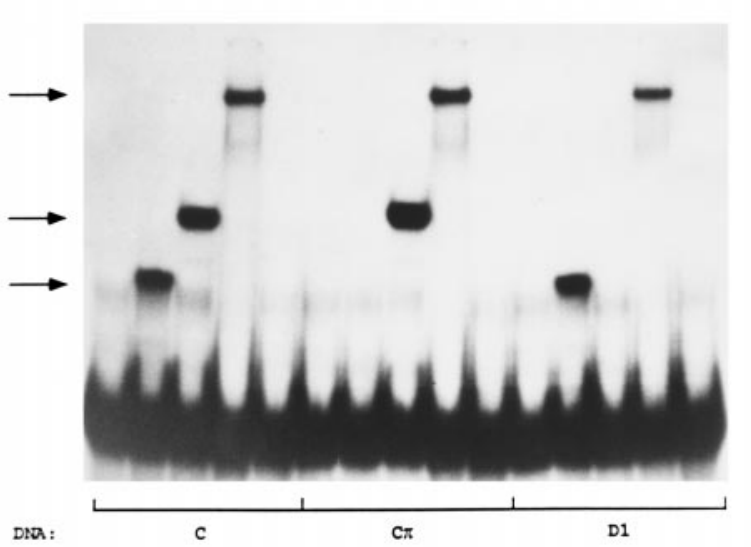

(b)

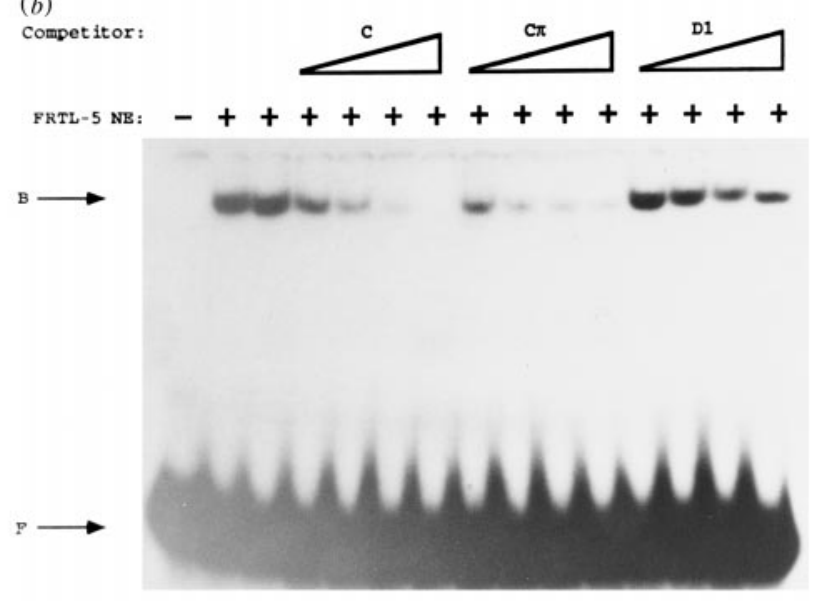

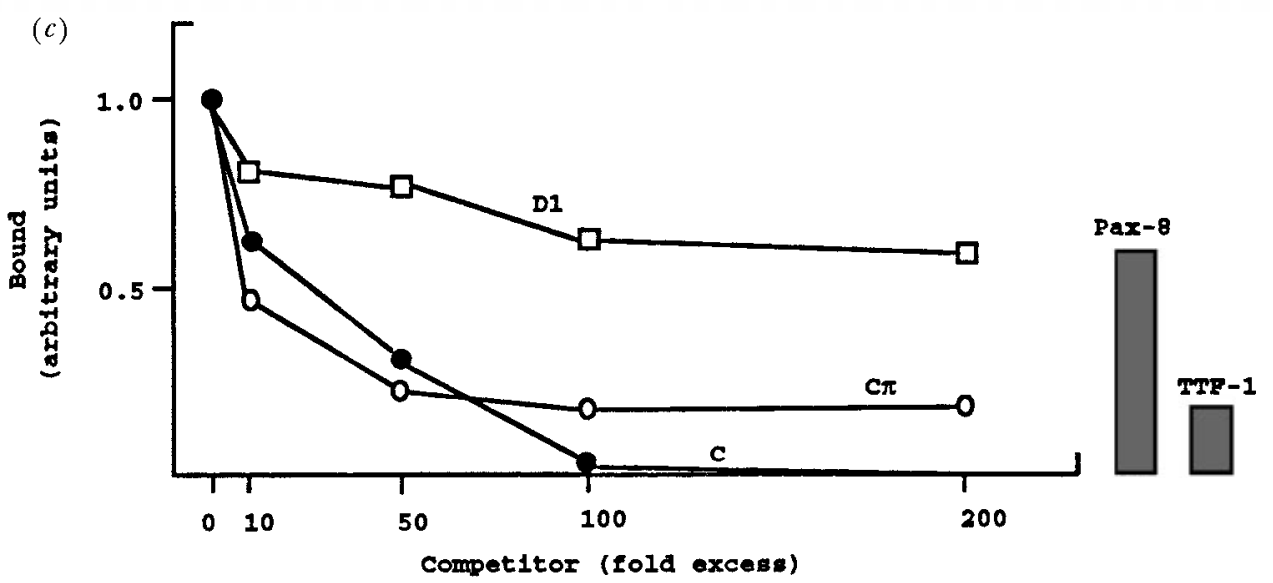

FIgURE 5. Relative amounts of Pax-8 and TTF-1 present in FRTL-5 nuclear extracts. (a) The oligonucleotides used as probes are indicated at the bottom of the autoradiogram, arrows indicate the protein-DNA complexes. Lanes 1,6 and 11, free probes; lanes 2, 7 and 12, probes incubated in the presence of TTF-1HD; lanes 3, 8 and 13, probes incubated in the presence of Pax-8; lanes 4, 9 and 14, probes incubated in the presence of FRTL-5 nuclear extracts; lanes 5, 10 and 15, probes incubated in the presence of NIH 3T3 nuclear extracts. $(b)$ Oligonucleotide C was used as a probe, the competitor oligonucleotides are shown above the autoradiogram. Nuclear extracts were prepared from FRTL-5 cells. (c) Autoradiographic signals shown in $(b)$ were quantitated by densitometric scanning and plotted against the fold excess of the competitor oligonucleotide. Bars at the right-hand side of the plots represent the relative amount of Pax-8 and TTF-1.

compete only with the signal due to Pax- 8 binding, while the latter should compete only with the signal due to TTF-1 binding. Therefore, signals observed in the presence of $\mathrm{C} \pi$ as a competitor should measure the amount of TTF-1, while signals observed in the presence of $\mathrm{D} 1$ as a competitor should measure the amount of $\mathrm{Pax}-8$. This approach was used with FRTL-5 nuclear extracts and the autoradiograms of the gel are shown in Fig. $5 b$. As expected, while the cold $\mathrm{C}$ sequence is able to abolish completely the signal due to the protein/ DNA complex, both the C $\pi$ and D1 sequences only partially reduce the intensity of the signal. Values of the protein-DNA complexes measured by densitometric scanning of the autoradiograms are shown in Fig. $5 c$. Since signals observed in the presence of D1 as a competitor measure the amount of Pax- 8 while signals observed in the presence of $\mathrm{C} \pi$ as a competitor measure the amount of TTF- 1, Pax- 8 levels appear to be threefold higher than TTF-1 levels. As the absence of TSH greatly reduces Pax-8, but not TTF-1, protein levels (Fig. 1), these data suggest that in the presence of the hormone the $\mathrm{C}$ site of $\mathrm{Tg}$ would be occupied by $\mathrm{Pax}-8$; in 
contrast, in the absence of TSH, TTF-1 binding would prevail over Pax- 8 binding.

\section{DISCUSSION}

By using two different approaches we provide evidence that $\mathrm{Pax}-8$ protein levels may regulate $\mathrm{Tg}$ gene expression in thyroid cells. In fact, (i) transfection of thyroid cells with a Pax-8 expression vector increases $\mathrm{Tg}$ promoter activity, and (ii) in human papillary cancers a significant correlation between Pax-8 and Tg mRNA levels is observed. Gel-retardation assays suggest that the mechanism by which the Pax- 8 protein levels modulate $\mathrm{Tg}$ promoter activity may occur through a competition with TTF-1 for a common binding site. Thus, in the context of the $\mathrm{C}$ site of $\mathrm{Tg}$ promoter, Pax-8 would activate the basal transcriptional machinery more efficiently than TTF-1. Accordingly, van der Kallen et al. (1996) demonstrated that in thyroid cells harbouring normal levels of TTF-1 but decreased levels of $\mathrm{Pax}-8$, Tg gene expression was abolished. Moreover, it has been demonstrated that the $\mathrm{C}$ terminus of Pax- 8 harbours a potent transactivation domain (Kozmik et al. 1993). It is interesting to observe that the function of this domain is subjected to a positive control by the cAMP-dependent protein kinase A (PKA) (Poleev et al. 1997). The Pax-8 DNA-binding activity also appears to be regulated. In fact, by using FRTL-5 cells, Kambe et al. (1996) have demonstrated that TSH activates Pax- 8 binding activity through modulation of the redox potential. These data suggest that TSH up-regulates $\mathrm{Tg}$ gene transcription by several integrated, Pax-8-dependent, mechanisms: increase of the $\mathrm{C}$ site occupancy through up-regulation of $\mathrm{Pax}-8$ protein levels and increase of the DNA-binding activity, and increase of the transactivation potential. Based upon these observations, we suggest that the transcription factor bound to the $\mathrm{C}$ site of $\mathrm{Tg}$ promoter would change depending on the hormonal stimulation, with TTF-1 or Pax-8 prevailing in the absence or the presence of TSH respectively.

Both in rat (as we have demonstrated in this study) and in dog (Van Renterghem et al. 1995), TSH up-regulates Pax-8 expression. Therefore, Pax-8 protein levels could represent an important determinant by which TSH regulates thyroid cells. The functional relationship existing between TSH and Pax- 8 in regulating thyroid cells is further suggested by the observations that either TSH receptor or Pax-8 inactivating mutations elicit thyroid hypoplasia (Abramowicz et al. 1997, Biebermann et al. 1997, Macchia et al. 1998).
Finally, our findings may provide the reason why thyroid defects are developed by subjects which are heterozygous for a loss-of-function mutation of a Pax-8 allele (Macchia et al. 1998). Since Pax-8 protein levels play an important regulatory role, a $50 \%$ reduction of the active protein levels should be sufficient to disrupt the normal regulatory network of the thyroid cell.

\section{ACKNOWLEDGEMENTS}

We thank R Di Lauro for providing Pax-8 and TTF-1 antibodies, P Gruss for providing the CMV-Pax-8 plasmid and L Tell for the improvement of the English style. This study is supported by grants to $\mathrm{G} D$ by the Associazione Italiana Ricerca Cancro (AIRC) and Consiglio Nazionale delle Ricerche (CNR: Target Project on Biotechnology). D F and L P are supported by the $\mathrm{PhD}$ programme Diagnosi e Terapie Cellulari e Molecolari of Udine University.

\section{REFERENCES}

Abramowicz MJ, Duprez L, Parma J, Vassart G \& Heinrichs C 1997 Familial congenital hypothyroidism due to inactivating mutation of the thyrotropin receptor causing profound hypoplasia of the thyroid gland. Fournal of Clinical Investigation 99 3018-3024.

Ambesi-Impiombato FS \& Coon HG 1979 Thyroid cells in culture. International Review of Cytology 10 163-172.

Biebermann H, Schoneberg T, Krude H, Schultz G, Gudermann T \& Gruters A 1997 Mutation of the human thyrotropin receptor gene causing thyroid hypoplasia and persistent congenital hypothyroidism. Fournal of Clinical Endocrinology and Metabolism 82 3471-3480.

Bradford M 1976 A rapid and sensitive method for quantitation of microgram quantities of protein utilizing the principle of protein-dye binding. Analytical Biochemistry 72 248-254.

Chamberlin HM, Palmer RE, Newman AP, Sternberg PW, Baillie DL \& Thomas JH 1997 The pax gene egl-38 mediates developmental patterning in Caenorhabdities elegans. Development 124 3919-3928.

Chomczynski P \& Sacchi N 1987 A single step method of RNA isolation by acid guanidinium thiocyanate-phenol-chloroform extraction. Analytical Biochemistry 162 156-159.

Church GM \& Gilbert W 1984 Genomic sequencing. Proceedings of the National Academy of Sciences of the USA 81 1991-1994.

Damante G, Pellizzari L, Esposito R, Fogolari F, Viglino P, Fabbro D, Tell G, Formisano S \& Di Lauro R 1996 A molecular code dictates sequence-specific DNA recognition by homeodomains. EMBO Fournal 15 4992-5000.

Fabbro D, Di Loreto C, Beltrami CA, Belfiore A, Di Lauro R \& Damante G 1994 Expression of thyroid-specific transcription factors TTF-1 and Pax-8 in human thyroid neoplasms. Cancer Research 54 4744-4749.

Fabbro D, Tell G, Leonardi A, Pellizzari L, Pucillo C, Lonigro R, Formisano S \& Damante G 1996 In the TTF-1 homeodomain the contribution of several amino acids to 
DNA recognition depends on the bound sequence. Nucleic Acids Research 24 3283-3288.

Francis-Lang H, Price M, Polycarpou-Schwarz M \& Di Lauro R 1992 Cell type-specific expression of the rat thyroperoxidase promoter indicates common mechanisms for thyroid-specific gene expression. Molecular and Cellular Biology 12 576-588.

van der Kallen CJ, Spierings DC, Thijssen JH, Blankenstein MA \& de Bruin TW 1996 Disrupted co-ordination of Pax-8 and thyroid transcription factor-1 gene expression in a dedifferentiated rat thyroid tumour cell line derived from FRTL-5. Fournal of Endocrinology 150 377-382.

Kambe F, Nomura Y, Okamoto T \& Seo H 1996 Redox regulation of thyroid-specific transcription factors, Pax-8 and TTF-1, is involved in their increased DNA-binding activities by thyrotropin in rat thyroid FRTL-5 cells. Molecular Endocrinology 10 801-812.

Kozmik Z, Kurzbauer R, Dorfler P \& Busslinger M 1993 Alternative splicing of $\mathrm{Pax}-8$ gene transcripts is developmentally regulated and generates isoforms with different transactivation properties. Molecular and Cellular Biology 13 6024-6035.

Macchia EP, Lapi P, Krude H, Pirro MT, Missero C, Chiovato L, Souabni A, Baserga M, Tassi V, Pinchera A, Fenzi G, Gruters A, Busslinger M \& Di Lauro R 1998 PAX-8 mutations associated with congenital hypothyroidism caused by thyroid dysgenesis. Nature Genetics 19 83-85.

Mansouri A, Hallonet M \& Gruss P 1996 Pax genes and their role in cell differentiation and development. Current Opinions in Cell Biology 8 851-857.

Musti AM, Ursini VM, Avvedimento EV, Zimarino V \& Di Lauro R 1987 A cell type-specific factor recognizes the rat thyroglobulin promoter. Nucleic Acids Research 15 8149-8166.

Poleev A, Okladnova O, Musti AM, Schneider S, RoyerPokora B \& Plachov D 1997 Determination of functional domains of the human transcription factor PAX-8 responsible for its nuclear localization and transactivating potential. European Fournal of Biochemistry 247 860-869.

Read AP 1995 Pax genes - paired feet in three camps. Nature Genetics $9333-334$.

Saito T, Endo T, Nakazato M, Kogai T \& Onaya T 1997 Thyroid-stimulating hormone-induced down-regulation of thyroid transcription factor 1 in rat thyroid FRTL-5 cells. Endocrinology 138 602-606.

Schedl A, Ross A, Lee M, Engelkamp D, Rashbass P, van Heyningen V \& Hastie ND 1996 Influence of PAX-6 gene dosage on development: overexpression causes severe eye abnormalities. Cell 86 71-82.

Schuppert F, Deiters S, Rambush E, Sierralta W, Dralle H \& von zur Muhlen A 1996 TSH-receptor expression and human thyroid desease: relation to clinical, endocrine and molecular thyroid parameters. Thyroid 6 575-587.

Strachan T \& Read AP 1994 Pax genes. Current Opinion in Genetics and Development 4 427-438.

Stuart ET \& Gruss P 1995 PAX genes: what's new in developmental biology and cancer? Human Molecular Genetics 4 1717-1720.

Stuart ET, Kiussi C \& Gruss P 1993 Mammalian Pax genes. Annual Review of Genetics 27 219-236.

Studier FW \& Moffat BA 1986 Use of bacteriophage T7 RNA polymerase to direct selective high-level expression of cloned genes. Fournal of Molecular Biology 189 113-130.

Tell G, Pellizzari L \& Damante G 1997 Transcription factors and cancer. The example of Pax genes. Advances in Clinical Pathology 1 243-256.

Van Renterghem P, Dremier S, Vassart G \& Christophe D 1995 Study of TTF-1 gene expression in dog thyrocytes in primary cultures. Molecular and Cellular Endocrinology 112 83-93.

Van Renterghem P, Vassart G \& Christophe D 1996 Pax-8 expression in primary cultured dog thyrocyte is increased by cyclic AMP. Biochimica et Biophysica Acta 1307 $97-103$.

Xu W, Rould MA, Jun S, Desplan C \& Pabo CO 1995 Crystal structure of a paired domain-DNA complex at $2 \cdot 5 \mathrm{~A}$ resolution reveals structural basis for Pax developmental mutations. Cell 80 639-650.

Zannini M, Francis-Lang H, Plachov D \& Di Lauro R 1992 Pax-8, a paired domain-containing protein, binds to a sequence overlapping the recognition site of a homeodomain and activates transcription from two thyroid-specific promoters. Molecular and Cellular Biology 12 4230-4241.

RECEIVED 26 May 1998 